\title{
Subglacial discharge weakens the stability of the Ross Ice Shelf around the grounding line
}

\author{
Yan Li, ${ }^{1,2}$ Hongling Shi, ${ }^{1,2}$ Yang Lu, ${ }^{1,2}$ Zizhan Zhang ${ }^{1,2}$ \& Hui Xi ${ }^{1,2}$ \\ 'State Key Laboratory of Geodesy and Earth's Dynamics, Innovation Academy for Precision Measurement Science and Technology, Chinese Academy of \\ Sciences, Wuhan, China; ${ }^{2}$ College of Earth and Planetary Sciences, University of Chinese Academy of Sciences, Beijing, China
}

\begin{abstract}
In this paper, we examine potential impact of discharge in Subglacial Lake Engelhardt, West Antarctica, on the stability of the Ross Ice Shelf around the grounding line by combining satellite altimetry and remote sensing images. According to satellite altimetry data from the Ice, Cloud and Land Elevation Satellite (ICESat; 2003-06), Subglacial Lake Engelhardt (SLE) discharged ca. $1.91 \pm 0.04 \mathrm{~km}^{3}$ of water into the downstream region. The ice-surface record derived from ICESat (2006-09) and CryoSat-2 (2011-17) data shows that the lake gained ca. $2.09 \pm 0.05 \mathrm{~km}^{3}$ of water during the refilling event following the drainage event, taking three times as much time to reach the previous water level before the discharge; the calculation demonstrates that water input from an upstream lake is unable to sustain water increase in SLE, indicating that the subglacial, hydrologic system and groundwater flow could have contributed to water increase in SLE via hydrologic networks. Satellite images captured surface depressions and crevasses at the drainage outlet point of hydrologic networks around the grounding line; satellite altimetry data show that the ice surface there is still depressing even though the subglacial discharge has finished, potentially reflecting the long-term impact of subglacial discharge on the stability of the immediate Ross Ice Shelf around the grounding line.
\end{abstract}

\section{Keywords}

Antarctic subglacial lakes; water storage change; satellite altimetry; remote sensing. hydraulic potential method

\section{Correspondence}

Hongling Shi, State Key Laboratory of Geodesy and Earth's Dynamics, Innovation Academy for Precision Measurement Science and Technology, 430077 Wuhan, China.E-mail: hlshi@asch.whigg.ac.cn

\author{
Abbreviations \\ DEM: digital elevation model \\ ERS-1: European Remote Sensing Satellite 1 \\ GLAS: Geoscience Laser Altimeter System \\ on ICESat \\ GLA12: level-2 altimetry product of GLAS \\ ICESat: Ice, Cloud and Land \\ Elevation Satellite \\ LP: lowest point \\ MOA04/MOA09: MODIS Mosaic of \\ Antarctica 2003-04/2008-09 image sets \\ MODIS: moderate resolution imaging \\ spectroradiometer instruments onboard \\ the Aqua and Terra satellites \\ NSIDC: National Snow and Ice Data Center, \\ Boulder, CO \\ RES: radio-echo sounding \\ SARIn: synthetic aperture radar \\ interferometric \\ SLE: Subglacial Lake Engelhardt \\ SLW7: Subglacial Lake Whillans 7
}

\section{Introduction}

Subglacial lakes are water bodies stored in hollows between the ice-sheet base and the substrate (Siegert 2000). As the largest known subglacial lake beneath the Antarctic Ice Sheet, Lake Vostok was discovered by RES (Oswald \& Robin 1973). McIntyre (1983) found more subglacial lakes by reanalysing previous RES observations. Surface depression over a lake near Lake Vostok, observed by Ridley et al. (1993) found that the information provided by ERS-1 correlates well with that of RES, proving that satellite altimetry is a valuable tool to detect subglacial lakes.
Observations from ICESat revealed that some lakes have drained and been refilled sequentially beneath the Whillans and Mercer ice streams, West Antarctica, between 2003 and 2006 (Fricker et al. 2007). Smith et al. (2009) identified 124 active subglacial lakes beneath the Antarctic continent using ICESat data between 2003 and 2008, in which the largest subglacial discharge was identified in Lake CookE2 (Wright \& Siegert 2012). McMillan et al. (2013) examined the ice-surface height change over Lake CookE2 using ICESat (2003-09) and Cryosat-2 (2011) data. Siegfried et al. (2014) and Siegfried \& Fricker (2018) estimated lake volume change over a decade, using available measurements within 
the lake outline. However, as slope changes around the lake shoreline can attenuate waveforms of radar points, radar measurements across the lake shoreline might be biased (Frappart et al. 2006; Silva et al. 2010). Uncertainties in water changes of subglacial lakes have not been comprehensively investigated (McMillan et al. 2013; Siegfried et al. 2014; Siegfried \& Fricker 2018), and the impact of subglacial discharge on the stability of the immediate ice shelf remains unclear.

In this paper, with the aim of contributing to the clarification of these issues, we present a case study conducted in SLE, East Antarctica, by means of satellite altimetry and satellite remote sensing. In our study, only satellite altimetry points around the LP on the ice surface are needed, reducing the requirement for a large number of data points to calculate the average height change. Water depths derived by hydraulic potential are used to constrain water changes around the lake shoreline. We present uncertainties in ice-surface height and lake-water volume change and reveal the hydrologic association among subglacial lakes, the subglacial hydrologic system and ground flows. We show the potential impact of SLE discharge on the stability of the Ross Ice Shelf around the grounding line.

\section{Study area and data}

\section{Study area}

Subglacial Lake Engelhardt is beneath the lower Whillans Ice Stream and close to the Ross Ice Shelf (Fig. 1), where the surface ice flow is very slow (Rignot $\&$ Scheuchl 2011). Subglacial Lake Engelhardt was selected as a case study for the following reasons: (1) the ice surface over SLE is covered by the CryoSat-2 SARIn mode, producing more measurements compared to the Low Resolution Mode (in the interior of the ice sheet); (2) Subglacial Lake Engelhardt is close to the drainage outlet point of the basal water pathways, which makes it possible to explore from where, and how upstream water flows into SLE, and what the hydrologic association is between upstream water and SLE, and (3) because SLE is over the upstream catchment of a drainage outlet point close to the Ross Ice Shelf around the grounding line, it is suitable for examining the potential impact from subglacial discharge on the stability of this large ice shelf.

\section{Data}

Satellite altimetry data used in this study include measurements from ICESat and CryoSat-2. The ICESat was

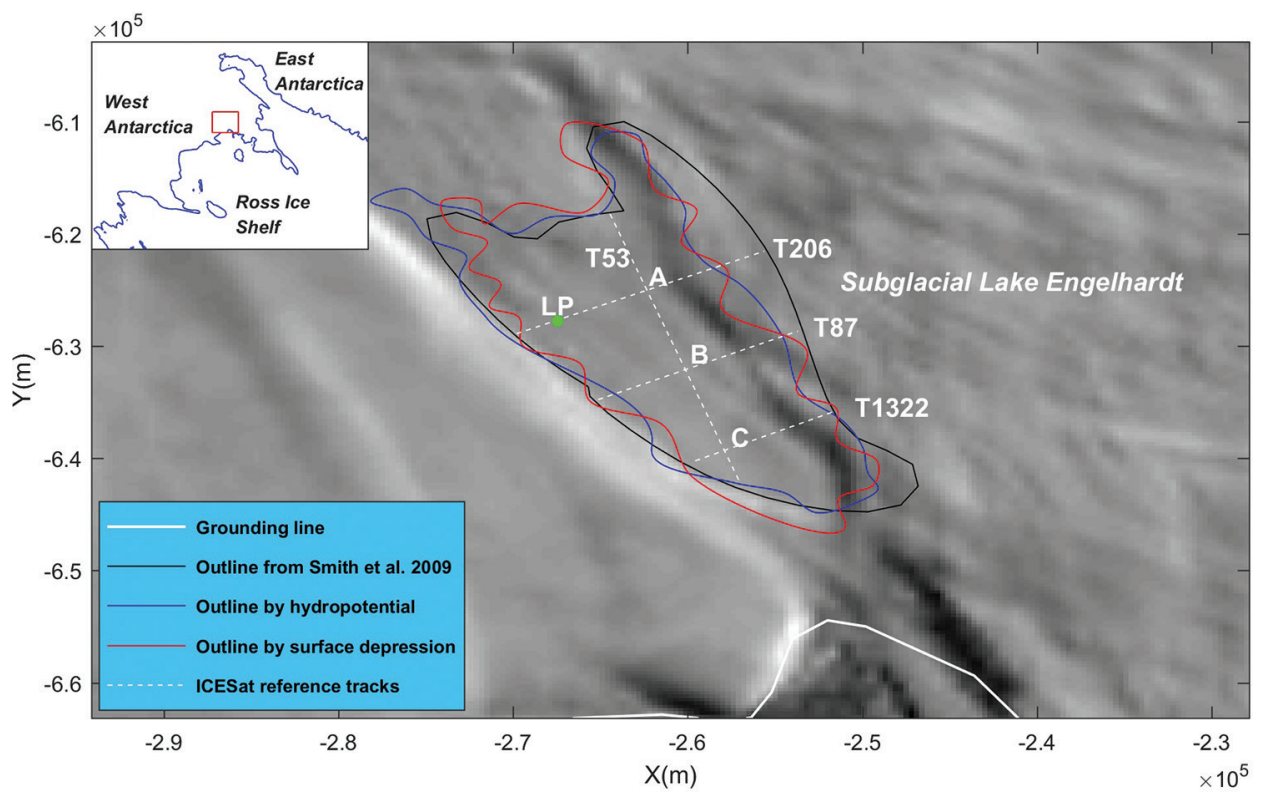

Fig. 1 Location of SLE and ICESat reference tracks across the ice-surface over SLE. The inserted panel shows the SLE's location in Antarctica. The black, blue and red lines denote outlines derived from satellite altimetry repeat-pass, hydraulic potential and surface depression methods, respectively. The solid, white line denotes the grounding line (Mouginot et al. 2017) around the Ross Ice Shelf. The white, dashed line denotes ICESat reference tracks, including T53, T87, T206 and T1322. LP denotes the lowest point obtained from our generated DEM. Points A, B and C are cross-over points intersected by different ICESat reference tracks. The background imagery is from MODIS (Haran et al. 2014). Coordinates are projected to the NSIDC Sea Ice Polar Stereographic South projection. 
launched in January 2003 with a polar orbit, with the intention of monitoring polar ice changes (Zwally et al. 2002). Along each ground track, successive footprints produced by GLAS laser transmitter are ca. $170 \mathrm{~m}$ away from each other. The footprint diameter is ca. $70 \mathrm{~m}$ and much smaller relative to footprints of conventional satellite radar altimetry (Zwally et al. 2015). Expected measurement accuracy is ca. $15 \mathrm{~cm}$ over the entire Antarctic Ice Sheet (Kwok et al. 2004; Fricker et al. 2005; Brenner et al. 2007). Although the GLAl2 (February 2003 to October 2009) elevation data have been corrected for geolocation offset, reflectivity, instrumental bias, atmospheric bias and tidal effects, potential outliers are filtered out according to data quality index and saturation bias in ranging (NSIDC 2014). The CryoSat-2 satellite was launched in April 2010 to determine variations in the thickness of the Earth's continental ice sheets and marine ice cover, and to understand the extent to which the Antarctic and Greenland ice sheets are contributing to global sea-level rise (ESA 2019). Over the ice sheet margins, ice-surface height is measured by the CryoSat-2 SARIn mode. Instrumental corrections, such as automatic gain control, signal phase and phase slope, have already been applied to the SARIn L2 product. In this study, we filter out anomalous points with backscatter value larger than $30 \mathrm{~dB}$, in accordance with the method used by Siegfried et al. (2014).

The Bedmap 2 data set provides ice thickness, surface and bed elevation data over the entire Antarctic continent (Fretwell et al. 2013). The Bedmap2 gives detailed continental bedrock topography $(1 \mathrm{~km} \times 1 \mathrm{~km})$, benefiting from the integration of multiple types of observations over the past decades. The high density of data is of importance to the hydraulic potential calculation in specific regions. Furthermore, uncertainties in ice thickness, surface and bed elevation are also included, which are necessary to assess the uncertainty of water depth estimates. The uncertainty in ice thickness and bed elevation is ca. $60 \mathrm{~m}$ in the SLE region (Fretwell et al. 2013).

\section{Methods}

\section{Cryosat-2 data bias}

Previous studies have identified several sources of error in CryoSat-2 SARIn data (Galin et al. 2013; McMillan et al. 2013; Wang et al. 2015), which should be corrected in the specific region of interest before CryoSat-2 data are used to construct time series of ice-surface height change with ICESat data. We determined the potential bias surrounding SLE as follows: (1) a $100 \mathrm{~m} \times 100 \mathrm{~m}$ digital elevation model (DEM) surrounding SLE was generated using CryoSat-2 data collected in 2011 by means of the bilinear interpolation method, covering an area of $3.2 \times 10^{3} \mathrm{~km}^{2}$; (2) the DEM was interpolated at each ICESat footprint to obtain height difference between the two data sets; (3) height residuals were filtered iteratively according to three-sigma rule until no outlier was detected. Finally, the mean of filtered-height difference was assumed as the intermission bias.

\section{Original water storage}

Water depths in a lake are subject to lake bed topography and hence are not uniform. With subglacial discharge, the lack of support from underlying water causes ice layers to drop. The depression process gradually ceases, starting at the shallows near the lake shoreline, where the ice base first makes contact with the bed, and then extending towards the deeper waters of the lake interior. At the conclusion of the depression process, height changes over the central area of the lake are larger than those close to the lake shoreline. Therefore, height change estimates based on altimetry samples over different areas would be various. Unlike ICESat, CryoSat-2 footprints are not repeated and are unevenly distributed over the ice surface. When these unevenly distributed points are used to calculate height change, the mean of height difference would be various as well. To reduce the potential bias, we used an adapted hydraulic potential method to derive hypothetical maximum water depth in SLE.

Hydraulic potential consists of elevation potential and water pressure at the ice base. Based on a previous study (Shreve 1972), a simplified hydraulic potential equation (Livingstone et al. 2013; Göller et al. 2016; Willis et al. 2016; Li et al. 2019) can be described as:

$$
\phi=\rho_{w} g b+P_{w}
$$

where, $\phi$ is hydraulic potential, $\rho_{w}$ is the water density $\left(1000 \mathrm{~kg} / \mathrm{m}^{3}\right), g$ is the gravitational acceleration, $b$ is the bed elevation and $P_{w}$ is water pressure, defined as:

$$
P_{w}=P_{i}-N=\rho_{i} g h-N
$$

where, $P_{i}$ is the overlying ice burden pressure, $\rho_{\mathrm{i}}$ is the ice density $\left(917 \mathrm{~kg} / \mathrm{m}^{3}\right), h$ is the ice thickness and $N$ is the effective ice pressure. Measurements beneath the Whillans Ice Stream showed that in situ subglacial effective pressure is within ca. $0.02-0.2 \%$ of the ice overburden pressure (Tulaczyk et al. 2010). For simplicity, $N$ can be assumed to be zero $(N=0)$. This leads to a substitution of $P_{w}$ by $P_{i}$ :

$$
\phi=\rho_{w} g b+\rho_{i} g h
$$


To simplify the calculation, Eqn. 3 is divided by $\rho_{w} g$ on both sides, turning Eqn. 3 into:

$$
\varphi=b+\frac{\rho_{i}}{\rho_{w}} h=b+0.917 h
$$

In Eqn. 4, $\varphi$ consists of only contributions from the ice overburden and bed elevation. The contribution from lake water is not considered. If we assume the maximum water depth is $w$ and surface elevation is $S$ in a grid cell, the true hydraulic potential should be described as:

$$
\varphi=b+0.917 h+w
$$

According to the geometric relation in elevation,

$$
h=s-b-w,
$$

we can substitute ice thickness $h$ with $(s-b-w)$ in Eqn. 4. Then Eqn. 4 is changed as follows:

$$
\begin{aligned}
\varphi & =b+0.917(s-b-w)+w \\
& =0.917 s+0.083 b+0.083 w
\end{aligned}
$$

However, water depths are unknown under most conditions and are typically set to 'zero'. Therefore, a typical hydraulic-potential calculation only considers the inputs from bed height and ice overburden; meaning that the calculated hydraulic potential is $0.083 w$ less than the true value in Eqn. 7. Value gaps in each grid cell are taken as sinks on the hydraulic potential surface. Here, we adopted an algorithm integrated in ArcGIS software to fill those sinks (depth $=0.083 w$ ) to their maximum depths (Livingstone et al. 2013). The filling process stops when the hydraulic potential surface reaches a critical state and any further input of water would lead water to drain. The water depth at each grid cell can be derived when the filled depth is divided by a constant 0.083 .

Uncertainties in surface and bed elevation can be reflected in the water depth estimates. Calculated uncertainty in water depth varies within $\pm 5 \mathrm{~m}$, according to error propagation laws. We added the uncertainties of the bed elevation and surface elevation to the surface and bed elevation data in Bedmap2. We derived another set of water depths using the same procedure. The difference between the two area estimates is assumed as the area uncertainty. Total water volume $v$ can be calculated as follows:

$$
v=s \cdot w
$$

where, $s$ denotes lake area and $w$ denotes mean water depth. According to error propagation laws, the uncertainty in volume can be expressed as:

$$
\sigma_{v}=\sqrt{w^{2} d s+s^{2} d w}
$$

We acknowledge that calculated water depths might be biased as the ice surface over SLE undulates with subglacial discharge and refilling. The calculation of hydraulic potential in this study differs from expressions adopted by previous studies (Livingstone et al. 2013; Göller et al. 2016; Willis et al. 2016) because we aimed to make full use of the present combination of surface elevation and bed elevation to reduce uncertainty in the volume estimate (Fretwell et al. 2013).

\section{Surface elevation change time series}

To determine whether surface elevation change is significantly affected by surface ice flow, we examined the surface elevation profile along an ICESat reference track. Three points (A, B and C in Fig. 1) along T53 were selected because these points were intersected by different ground tracks. Surface elevation measurements from subsequent studies were projected onto the ground track in February 2003. In each study, calculated elevation differences with respect to the CryoSat-2 DEM over surrounding regions was subtracted from all altimetry points within the lake area.

After non-hydrology effects were assessed or reduced, we constructed a long-term time series of ice-surface elevation change by combining the two satellite altimetry data. For ICESat points, we projected the LP to the T206 line in each campaign. If the interpolated point around the LP was within ca. $70 \mathrm{~m}$, we straightaway took the interpolated elevation as a repeated LP observation (Zwally et al. 2002; Schutz et al. 2005; Moholdt et al. 2010) as this distance was within the diameter of the ICESat footprint. The accuracy of the ICESat measurement was assumed to represent the error of the surface elevation at the LP; when the interpolated point was more than $70 \mathrm{~m}$ away from the LP, we conducted a slope correction using the CryoSat-2 DEM. Given this condition, we assumed the error of elevation change is composed of errors from the ICESat measurement and the CryoSat-2 DEM. Calculation shows that the farthest point was $220 \mathrm{~m}$ away from the LP. We assumed this distance would not cause a large elevation bias as long as the surface slope correction was conducted. For CryoSat-2 data, we constructed yearly DEMs using the processing method described earlier. Although the ice surface over the lake kept changing during the observation period, we assumed that the LP on the DEM surface was still the lowest, on account of the previous depression. Then we subtracted the elevation values from each DEM at the LP to construct yearly time series. The work flow is shown in Fig. 2. The error of the ice-surface elevation change was assigned as the accuracy of the CryoSat-2 measurement. 


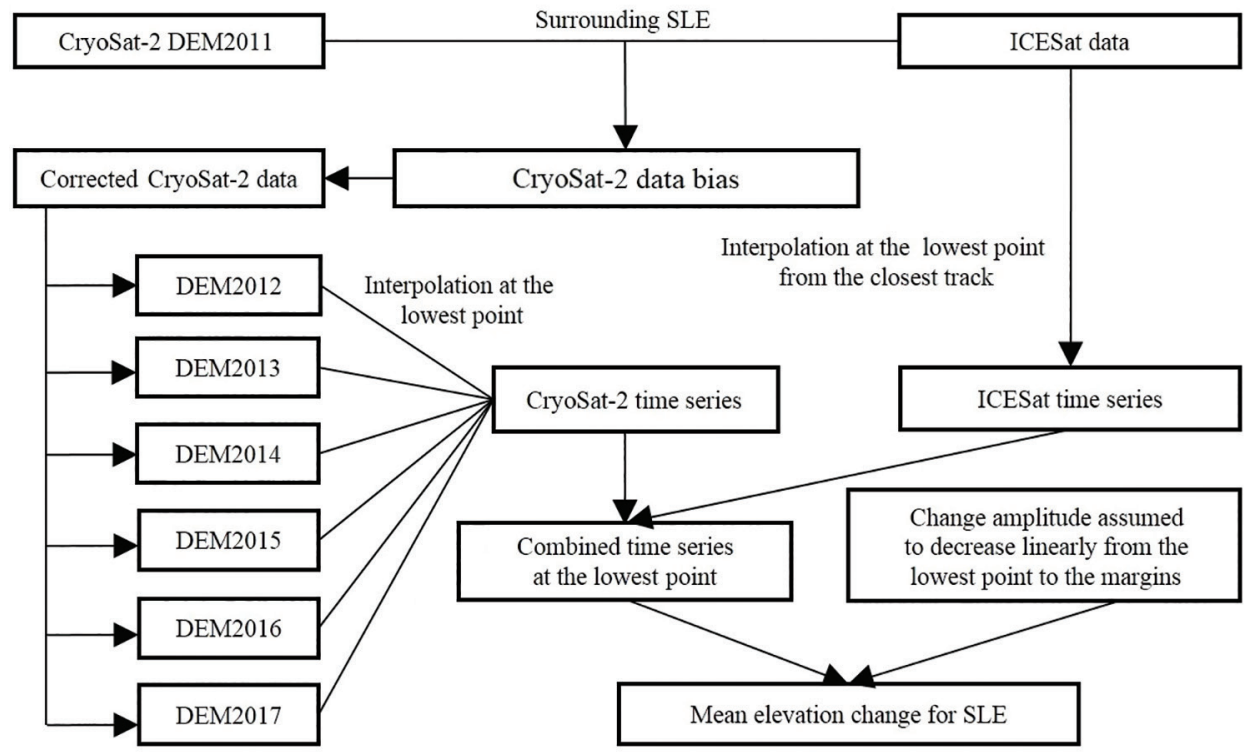

Fig. 2 Work flow used to derive mean surface elevation change over SLE.

\section{Spatial distribution of elevation change around SLE}

CryoSat-2 data (2010-17) were used to investigate the spatial distribution of elevation change surrounding SLE. To make full use of the available CryoSat-2 data, an adapted repeat-track analysis was adopted (Legrésy et al. 2006; Flament \& Rémy 2012; McMillan et al. 2014). The designated region is divided into $5 \mathrm{~km} \times 5 \mathrm{~km}$ gridded geographic units. In each grid cell, we used a quadratic function of the surface terrain $(x, y)$ and a linear function of time $(t)$, as shown below in Eqn. 10, to estimate surface elevation change between 2010 and 2017:

$h(x, y, t)=h_{0}+a_{1} x+a_{2} y+a_{3} x y+a_{4} x^{2}+a_{5} y^{2}+a_{6} t$

where $h$ is elevation, $x$ and $y$ are coordinates in the Polar Stereographic South projection, $t$ is the observation time, $h_{0}$ is the mean surface elevation, $a_{1^{\prime}} a_{2^{2}} a_{3^{\prime}} a_{4}$ and $a_{5}$ are used to account for surface terrain, $a_{6}$ is the estimated elevation change rate. In each grid, data were iteratively filtered according to the three-sigma rule. Poorly constrained solutions (>10 m/year) were discarded (Helm et al. 2014; McMillan et al. 2014).

\section{Results and discussion}

\section{Cryosat-2 elevation bias}

The intermission elevation bias was estimated to be ca. $-1.46 \pm 0.73 \mathrm{~m}$ (CryoSat-2 relative to ICESat) and corrected in all CryoSat-2 measurements after iteration processing (Fig. 3). The remaining $-0.79 \mathrm{~m}$ offset was attributed to snowpack penetration after a $-0.67 \mathrm{~m}$ instrument bias was subtracted from the total bias in this study (McMillan et al. 2013). In an experiment before CryoSat-2 was launched, a $-0.91 \mathrm{~m}$ bias was assumed to be caused by radar penetration into the snowpack, according to airborne radar observations in the regions having steep terrain (Hawley et al. 2009). McMillan et al. (2013) derived a $-0.87 \mathrm{~m}$ radar penetration bias using similar method. Study area difference may account for the discrepancy between biases in radar penetration.

\section{Coverage comparison}

We estimate the SLE coverage to be ca. $348 \pm 8 \mathrm{~km}^{2}$ using the hydraulic potential method, which agrees well with the ca. $360 \mathrm{~km}^{2}$ depression area on the CryoSat-2 DEM (Fig. lb). Previous studies estimated the coverage of SLE to be ca. 339 and ca. $341 \mathrm{~km}^{2}$, respectively (Siegfried et al. 2016; Siegfried \& Fricker 2018). The comparison proves the feasibility of the hydraulic potential method to estimate the area of SLE. This reaffirms that surface depressions over active subglacial lakes can also be used to estimate subglacial area if detailed subglacial bed topography is absent and we are unable to calculate hydraulic potential.

\section{Original water storage}

Using the method we developed, we calculated water depth in each grid cell within the area of SLE (Fig. 4), 

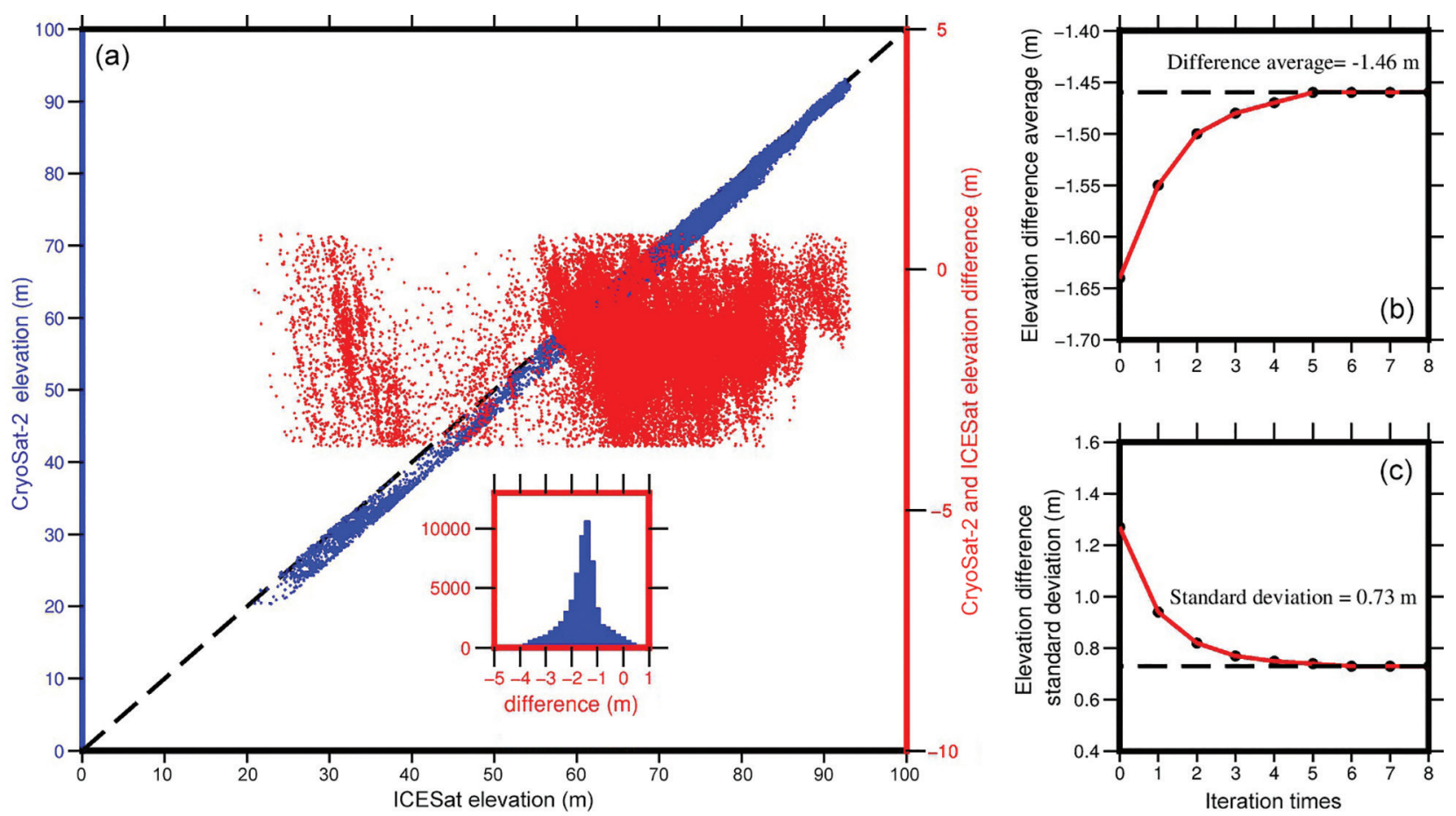

Fig. 3 Comparison of elevation data from ICESat and CryoSat-2: (a) Blue points indicate ICESat (2003-09) and bilinear interpolated coincident CryoSat-2 (2011) points in $3.2 \times 10^{3} \mathrm{~km}^{2}$ areas around SLE. Red points indicate elevation differences between CryoSat-2 and ICESat data (CryoSat-2 minus ICESat). The histogram indicates corresponding elevation differences (CryoSat-2 minus ICESat). (b) The elevation difference average. (c) The standard deviation of the elevation difference. Both, the average of the final elevation difference and its standard deviation, are derived by iterative $3 \sigma$ filtering applied to residual observations at each time until their final estimates become stable.

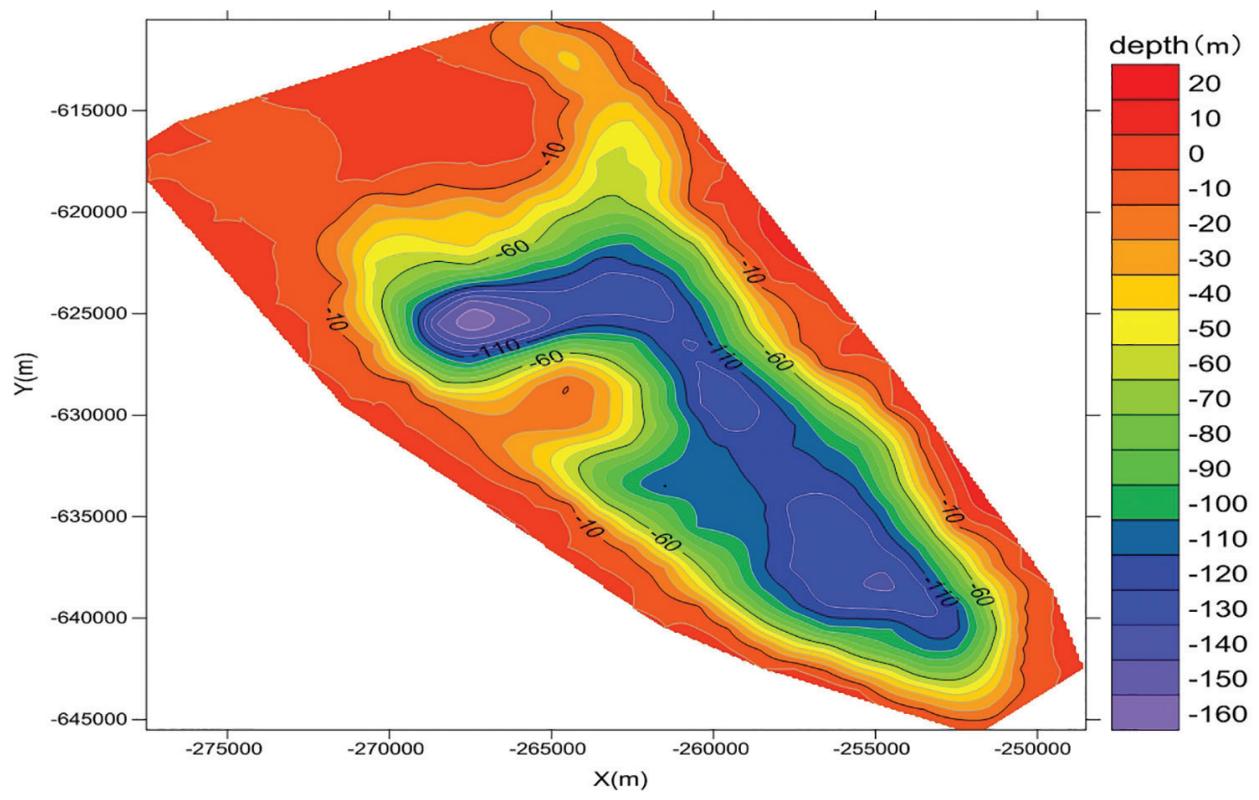

Fig. 4 Depths of SLE derived from the hydraulic potential method are gridded in a spatial resolution of $1 \mathrm{~km} \times 1 \mathrm{~km}$ to show the local terrain. The map is in the Polar Stereographic South projection. The depth datum is the lake's surface. Depths are denoted by negative values. Positive depth values are meaningless on account of interpolation. 

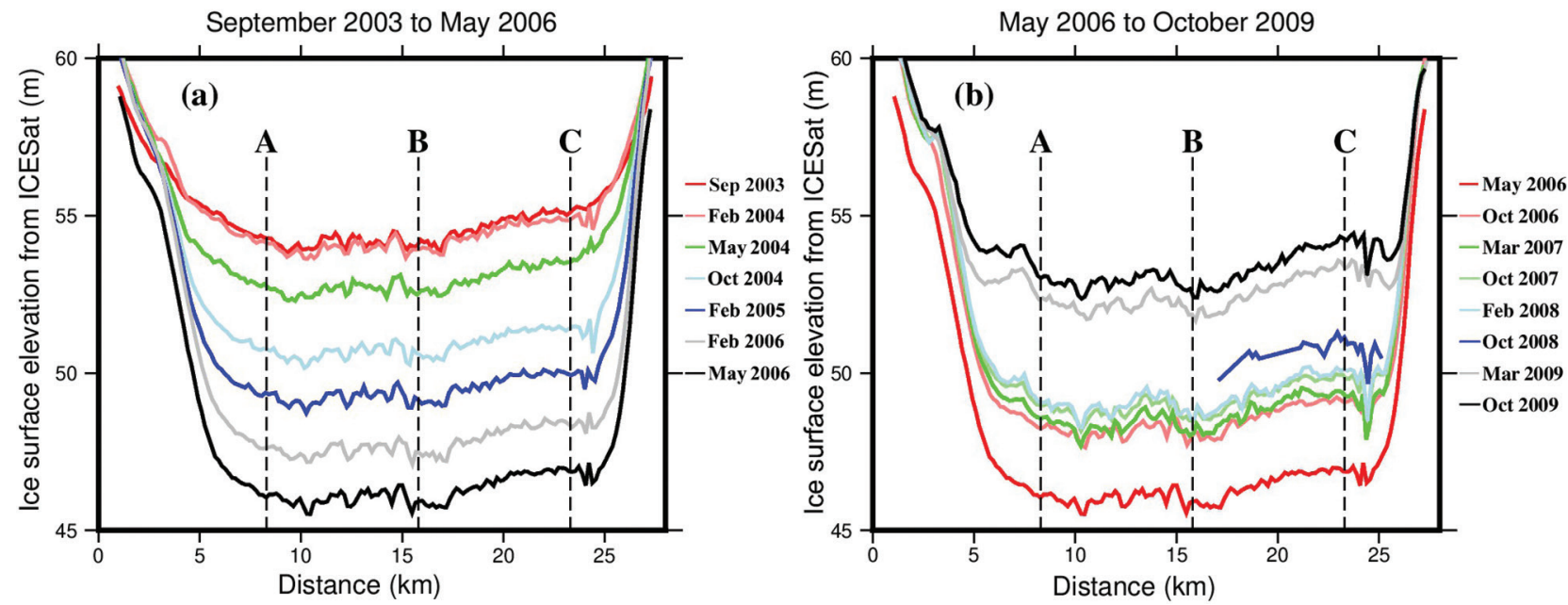

Fig. 5 ICESat observations along track 53 (T53) over the SLE surface from south to north. A, B and C indicate three points close to the intersecting tracks. (a) Surface depressed continuously from February 2003 to May 2006 (red line to black line) (b) Surface uplifted continuously from May 2006 to October 2009 (red line to black line).

from which we determined the mean depth of SLE to be ca. $65.7 \pm 0.27 \mathrm{~m}$. The lake contains ca. $22.86 \pm 0.53 \mathrm{~km}^{3}$ of water. It should be noted that the volume we calculated is the maximum, hypothetical water storage. When we calculated water depths, surface elevation were assumed to be at the maximum values in each grid cell throughout the study period.

\section{Time series of ice-surface elevation change over SLE}

As is shown in Fig. 5, ice-surface displacement along T53 are synchronous in each ICESat campaign, indicating that the surface depression and uplift over SLE are not significantly affected by horizontal ice flow (Fig. 5). This evidence supports our assumption that ice surface depression can be approximately represented by the displacement at the LP on the DEM (LP in Fig. 1b).

The ice surface kept dropping from September 2003 to May 2006 (Fig. 6a), and the ice surface at the LP subsided by a total of ca. $11 \mathrm{~m}$ in 3.25 years at the rate of ca. $-3.4 \pm 0.2 \mathrm{~m} /$ year. The continuous subsidence reflects a drainage event process in SLE. From May 2006 to December 2017, the total ice surface uplift reached ca. $12 \mathrm{~m}$, at a rate of ca. $1.1 \pm 0.28 \mathrm{~m} /$ year at LP. Given the current refilling rate along with rapid drainage, SLE requires a long time to recover its pre-2003 water level, provided the present filling rate is sustained.

In this study, our analysis is based on the assumption that ice surface displacement at the LP represents the maximum amplitude of ice surface displacements within the lake coverage. In fact, the ice base is in contact with the bedrock in the interior of the lake and only some water remains. The weight of the overlying ice causes downward deflection of ice layers. To derive the mean surface elevation change over SLE, we assumed that the amplitude of surface changes over the subglacial lake decreases linearly from the LP to the lake shoreline. According to this assumption, the ice surface amplitude at LP is twice that of the spatial mean change over SLE. So the mean depression and uplift rates reached only ca. $-1.7 \pm 0.1$ and ca. $0.55 \pm 0.14 \mathrm{~m} /$ year, respectively, during our study period. The mean ice-surface change rate arrived at in this study corresponds with that from a previous study (ca. $0.3-0.5 \mathrm{~m} /$ year) by Siegfried \& Fricker (2018).

\section{Volume change}

Until the end of the drainage event, ice surface around the lake margins cannot depress much because water depths around the lake shoreline are much shallower than those beneath the ice surface at the LP. Assuming a homogeneous ice-surface depression would therefore lead to overestimated water loss (McMillan et al. 2013). By means of the coverage and water depths derived, using the hydraulic potential method, we estimated the total water loss in SLE to be ca. $1.91 \pm 0.04 \mathrm{~km}^{3}$ during the drainage event. Using repeated track analysis, based on 2003-05 ICESat data, Smith et al. (2009) derived a water loss of ca. $1.8 \mathrm{~km}^{3}$, which agrees well with our estimate. 

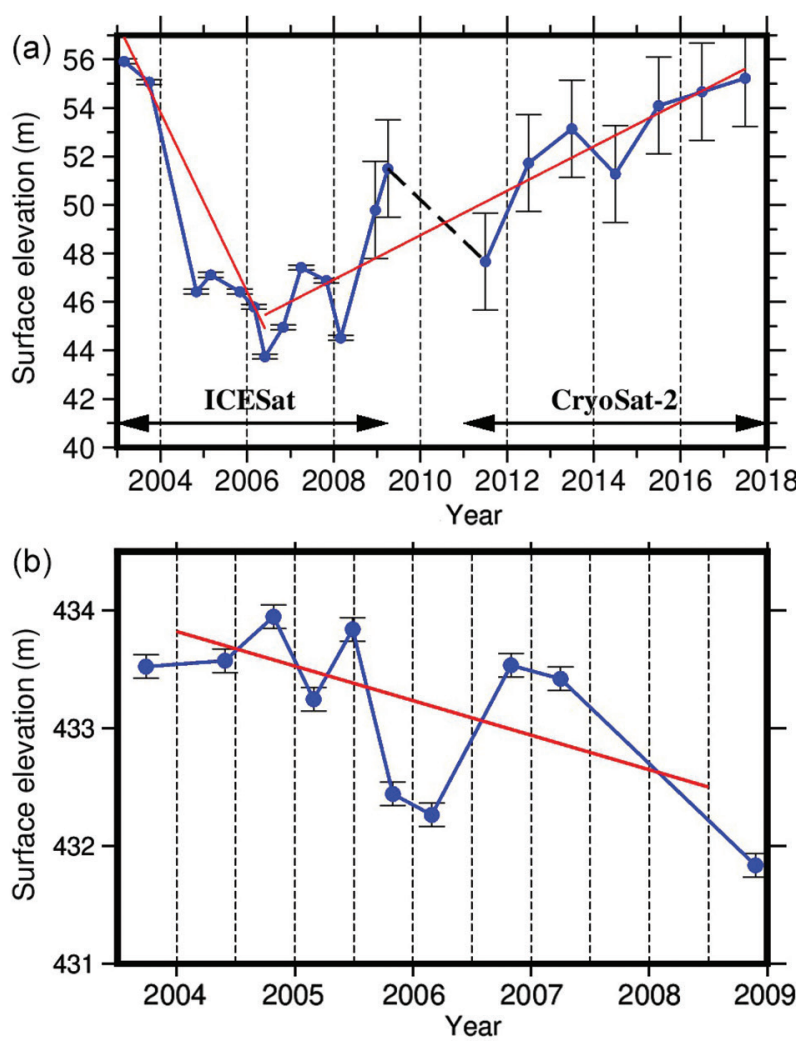

Fig. 6 (a) Elevation change derived from ICESat (February 2003 to October 2009) and CryoSat-2 (2010 -17) at the LP on the ice surface over SLE. The black, dashed line indicates no repeated observations were available between the two altimetry missions. The red lines indicate linear trends during 2003 to 2006 and 2006 to 2017 using linear regression. (b) Surface elevation changes in SLW7 derived from ICESat data from 2003 to 2009. The red lines indicate linear trends during 2003 to 2009 using linear regression.

Since May 2006, the ice surface began to uplift, regaining its original elevation in 2015 and continued to uplift, subsequently. Here also, we used our estimated coverage as the accumulation area because no time-variant bed elevation could be obtained to estimate the coverage change. This might lead to underestimation of the total volume of water change during the refilling event. Finally, we estimated the total volume of water increase to be ca. $2.09 \pm 0.05 \mathrm{~km}^{3}$ in the refilling period.

\section{Hydrologic connections via basal water pathways}

Basal water pathways are assumed to be widespread beneath the ice base in Antarctica (Pattyn 2008; Wright et al. 2008). During drainage and refilling events, water can be transported beneath the thick ice. To explore potential hydrological connections between SLE and upstream subglacial lakes, we surveyed the area upstream of SLW7 using the hydraulic potential as described earlier in this paper. We calculated water storage change from 2003 to 2009 (ICESat measurements only) in SLW7 using the same approach that we had adopted for SLE. Water loss in SLW7 during this period was ca. $0.1 \pm 0.05 \mathrm{~km}^{3}$. If we assume that all the water in SLW7 drained into SLE, it does not account for the water increase in SLE. Considering the disparity in water loss in SLW7 and the increment in SLE, it indicates that the water increase in SLE is unlikely to be entirely caused by the discharge from SLW7. It suggests that the water increase in SLE also includes water from hydrologic networks and groundwater flow (Christoffersen et al. 2014).

In hydraulic potential theory, basal water flows in the direction of the gradient of hydraulic potential (Willis et al. 2016). To correlate the depression with the water transport pathways (Fig. 7b; Goeller 2014), remote sensing images are used to deduce the surface depression process. Remote sensing images from the MODIS based MOA04 set show a significant surface depression over SLE (Scambos et al. 2007) (Fig. 7c). Furthermore, a crevasse can be seen on the depressed surface from the MOA09 image (Fig. 7d; Haran et al. 2014). Surface crevasses have been found in recent studies of other regions (Willis et al. 2015; Bell et al. 2017; Kingslake et al. 2017) and it has been suggested that they are traces left by surface melt. No research has shown the existence of surface water in the SLE region thus far. We calculated surface elevation change around SLE using CryoSat-2 measurements during 2010-17 by employing the method described earlier. Over the downstream region of SLE, we found an area close to the grounding line where the ice surface kept depressing from 2010 to 2017 (Fig. 7a). Here, we assumed that water from SLE entered the cavity beneath the ice shelf and caused further basal melting (Fricker \& Scambos 2009; Carter \& Fricker 2012), leaving crevasses over the ice surface around the grounding line.

\section{Summary}

In this study, a 15-year record of SLE water change was constructed by combining satellite altimetry data from ICESat and CryoSat-2. Our results indicate that refilling takes three times as much time as it takes to drain. Water change around the lake shoreline is constrained by water depths derived from the hydraulic potential method. The lake area determined by surface depression and hydraulic 

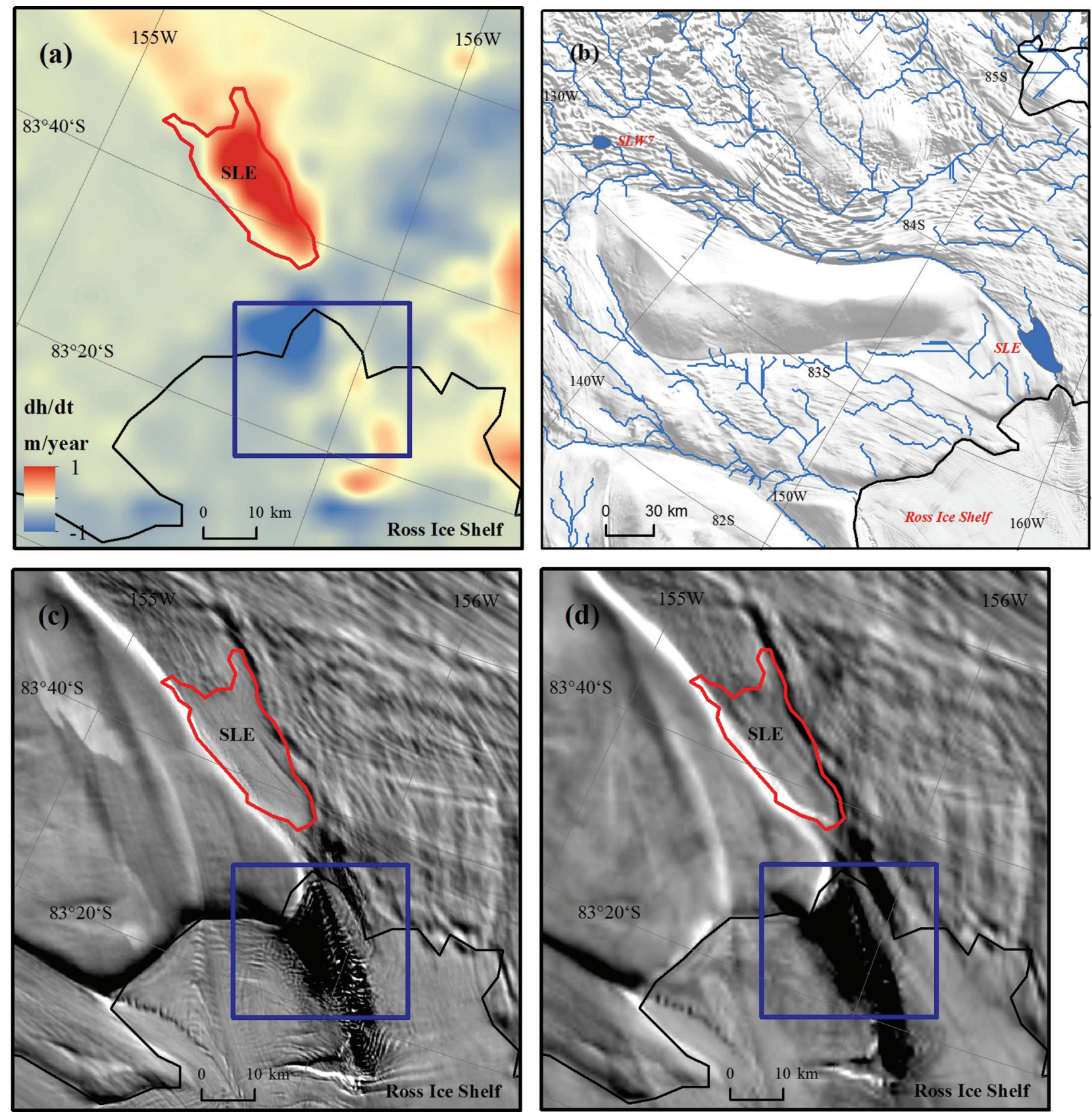

Fig. 7 (a) Estimated elevation change based on data provided by Cryoast-2 from July 2010 to November 2017. Red line indicates the outline of SLE from the NSIDC (Smith et al. 2009). (b) Water networks around the Ross Ice Shelf (data provided by Sebastian Göller, pers. comm.). Blue polygons indicate SLE and upstream SLW7. Background images are from (c) MOA04 and (d) MOA09 (Scambos et al. 2007; Haran et al. 2014). The red line indicates the outline of SLE (Smith et al. 2009) in (c) and (d). The black line indicates the grounding line (Mouginot et al. 2017) around the Ross Ice Shelf. The map projection is the Polar Stereographic South projection. For (a), (c) and (d), blue squares indicate the same region close to SLE.

potential method agree well with previous estimates. In addition to the upstream lake SLW7, hydrologic networks and ground flows also potentially contribute to the increase of water in SLE. Continuous surface depression is found on the surface of the Ross Ice Shelf close to the grounding line: remote sensing images captured significant surface crevasses, which indicates that the subglacial discharge may have exacerbated ice melt beneath the Ross Ice Shelf around the grounding line, potentially threatening the stability of this large ice shelf. 


\section{Acknowledgements}

We thank the NSIDC and the European Space Agency for providing the ICESat, lake boundaries and CryoSat-2 data, respectively. We thank Sebastian Göller for providing water flux data. Finally, we thank the Subject Editor and reviewers for their comments, which improved the manuscript.

\section{Disclosure statement}

The authors report no conflict of interest.

\section{Funding}

This work was jointly funded by the National Natural Science Foundation of China (grant nos. 41674085, 41774022 and 41604009) and the Basic Frontier Science Research Program of the Chinese Academy of Sciences (grant no. ZDBS-LY-DQC028).

\section{References}

Bell R.E., Chu W., Kingslake J., Das I., Tedesco M., Tinto K.J., Zappa C.J., Frezzotti M., Boghosian A. \& Lee W.S. 2017. Antarctic ice shelf potentially stabilized by export of meltwater in surface river. Nature 544, 344-348, doi: 10.1038/ nature22048.

Brenner A.C., Dimarzio J.P. \& Zwally H.J. 2007. Precision and accuracy of satellite radar and laser altimeter data over the continental ice sheets. IEEE Transactions on Geoscience and Remote Sensing 45, 321-331, doi: 10.1109/ tgrs.2006.887172.

Carter S.P. \& Fricker H.A. 2012. The supply of subglacial meltwater to the grounding line of the Siple Coast, West Antarctica. Annals of Glaciology 53, 267-280, doi: 10.3189/2012AoG60A119.

Christoffersen P., Bougamont M.C., Sasha P., Fricker H.A. \& Tulaczyk S. 2014. Significant groundwater contribution to Antarcticice streams hydrologic budget. Geophysical Research Letters 41, 2003-2010, doi: 10.1002/2014gl059250.

ESA 2019. CryoSat-2 product handbook. European Space Agency. Accessed on the internet at https://earth.esa. int/documents/10174/125272/CryoSat-Baseline-D-Product-Handbook on 30 September 2020.

Flament T. \& Rémy F. 2012. Dynamic thinning of Antarctic glaciers from along-track repeat radar altimetry. Journal of Glaciology 58, 830-840, doi: 10.3189/2012jog 1 1j1 18.

Frappart F., Calmant S., Cauhopé M., Seyler F. \& Cazenave A. 2006. Preliminary results of ENVISAT RA-2-derived water levels validation over the Amazon Basin. Remote Sensing of Environment 100, 252-264, doi: 10.1016/j.rse.2005.10.027.

Fretwell P., Pritchard H.D., Vaughan D.G. \& Bamber J.L. 2013. Bedmap2: improved ice bed, surface and thickness datasets for Antarctica. Cryosphere 7, 375-393, doi: 10.5194/tc-7-375-2013.

Fricker H.A., Borsa A., Minster B., Carabajal C., Quinn K. \& Bills B. 2005. Assessment of ICESat performance at the salar de Uyuni, Bolivia. Geophysical Research Letters 32, L21S06, doi: 10.1029/2005gl023423.

Fricker H.A. \& Scambos T. 2009. Connected subglacial lake activity on lower Mercer and Whillans ice streams, West Antarctica, 2003-2008. Journal of Glaciology 55, 303-315, doi: $10.3189 / 002214309788608813$.

Fricker H.A., Scambos T., Bindschadler R. \& Padman L. 2007. An active subglacial water system in West Antarctica mapped from space. Science 315, 1544-1548, doi: 10.1126/ science.1136897.

Galin N., Wingham D.J., Cullen R., Fornari M., Smith W.H. \& Abdalla S. 2013.Calibration of the CryoSat-2 interferometer and measurement of across-track ocean slope. IEEE Transactions on Geoscience and Remote Sensing 51, 57-72, doi: 10.1109/TGRS.2012.2200298.

Göller S. 2014. Antarctic subglacial hydrology-interactions of subglacial lakes, basal water flow and ice dynamics. PhD thesis, University of Bremen.

Göller S., Steinhage D., Thoma M. \& Grosfeld K. 2016. Assessing the subglacial lake coverage of Antarctica. Annals of Glaciology 57, 109-117, doi: 10.1017/aog.2016.23.

Haran T., Bohlander J., Scambos T., Painter T. \& Fahnestock M. 2014. MODIS Mosaic of Antarctica 2008-2009 (MOA2009) image map. Boulder, CO: National Snow and Ice Data Center. Doi: $10.7265 /$ N5KP8037.

Hawley R., Shepherd A., Cullen R., Helm V. \& Wingham D. 2009. Ice-sheet elevations from across-track processing of airborne interferometric radar altimetry. Geophysical Research Letters 36, 297-304, doi: 10.1029/2009GL040416.

Helm V., Humbert A. \& Miller H. 2014. Elevation and elevation change of Greenland and Antarctica derived from CryoSat-2. The Cryosphere 8, 1539-1559, doi: 10.5194/ tc-8-1539-2014.

Kingslake J., Ely J.C., Das I. \& Bell R.E. 2017. Widespread movement of meltwater onto and across Antarctic ice shelves. Nature 544, 349-352, doi: 10.1038/nature22049.

Kwok R., Zwally H.J. \& Yi D. 2004. ICESat observations of Arctic sea ice: a first look. Geophysical Research Letters 31, 171-184, doi: 10.1029/2004gl020309.

Legrésy B., Rémy F. \& Blarel F. 2006. Paper presented at the Symposium on 15 Years of Progress in Radar Altimetry. 13-18 March, Venice.

Li Y., Lu Y. \& Zhang Z. 2019. Characterizing three-dimensional features of Antarctic subglacial lakes from the inversion of hydraulic potential-Lake Vostok as a case study. Advances in Polar Science 30, 70-75, doi: 10.13679/j. advps.2019.1.00070.

Livingstone S.J., Clark C.D., Woodward J. \& Kingslake J. 2013. Potential subglacial lake locations and meltwater drainage pathways beneath the Antarctic and Greenland ice sheets. Cryosphere 7, 1721-1740, doi: 10.5194/ tc-7-1721-2013.

McIntyre N.F. 1983. The topography and flow of the Antarctic Ice Sheet. PhD thesis, Scott Polar Research Institute, University of Cambridge. 
McMillan M., Corr H., Shepherd A., Ridout A., Laxon S. \& Cullen R. 2013. Three-dimensional mapping by CryoSat- 2 of subglacial lake volume changes. Geophysical Research Letters 40, 4321-4327, doi: 10.1002/grl.50689.

McMillan M., Shepherd A., Sundal A., Briggs K., Muir A., Ridout A., Hogg A. \& Wingham D. 2014. Increased ice losses from Antarctica detected by CryoSat-2. Geophysical Research Letters 41, 3899-3905, doi: 10.1002/2014GL060111.

Moholdt G., Nuth C., Hagen J.O. \& Kohler J. 2010. Recent elevation changes of Svalbard glaciers derived from ICESat laser altimetry. Remote Sensing of Environment 114, 2756-2767, doi: 10.1016/j.rse.2010.06.008.

Mouginot B., Scheuchl J. \& Rignot E. 2017. MEaSUREs Antarctic boundaries for IPY 2007-2009 from satellite radar. Version 2. Boulder, CO: National Snow and Ice Data Center. doi: 10.5067/AXE4121732AD.

NSIDC (National Snow and Ice Data Center) 2014. GLAS altimetry product usage guidance. Accessed on the internet at https://nsidc.org/sites/nsidc.org/files/files/NSIDC_AltUserGuide_Rel29.pdf on 30 September 2020.

Oswald G.K.A. \& Robin G.D.Q. 1973. Lakes beneath the Antarctic Ice Sheet. Nature 245, 251-254, doi: 10.1038/ 245251 la0.

Pattyn F. 2008. Investigating the stability of subglacial lakes with a full Stokes ice-sheet model. Journal of Glaciology 54 , 353-361, doi: 10.3189/002214308784886171.

Ridley J.K., Wyn C. \& Laxon S.W. 1993.Identification of subglacial lakes using ERS-1 radar altimeter. Journal of Glaciology 39, 625-634, doi: 10.3189/S002214300001652X.

Rignot E. \& Scheuchl B. 201 1. Ice flow of the Antarctic Ice Sheet. Science 333, 1427-1430, doi: 10.1126/science.1208336.

Scambos T.A., Haran T.M., Fahnestock M.A., Painter T.H. \& Bohlander J. 2007. MODIS-based Mosaic of Antarctica (MOA) data sets: continent-wide surface morphology and snow grain size. Remote Sensing of Environment 111, 242-257, doi: 10.1016/j.rse.2006.12.020.

Schutz B.E., Zwally H.J., Shuman C.A., Hancock D. \& Dimarzio J.P. 2005. Overview of the ICESat mission. Geophysical Research Letters 32, 97-1 16, doi: 10.1029/2005gl024009.

Shreve R.L. 1972. Movement of water in glaciers. Journal of Glaciology 11, 205-214, doi: 10.3189/s002214300002219x.

Siegert M.J. 2000. Antarctic subglacial lakes. Earth-Science Reviews 50, 29-50, doi: 10.1016/S0012-8252(99)00068-9.

Siegfried M.R. \& Fricker H.A. 2018. Thirteen years of subglacial lake activity in Antarctica from multi-mission satellite altimetry. Annals of Glaciology 5, 42-55, doi: 10.1017/ aog.2017.36.

Siegfried M.R., Fricker H.A., Carter S.P. \& Tulaczyk S. 2016. Episodic ice velocity fluctuations triggered by a subglacial flood in West Antarctica: dynamic changes due to subglacial flood. Geophysical Research Letters 43, 2640-2648, doi: 10.1002/2016gl067758.

Siegfried M.R., Fricker H.A., Roberts M., Scambos T.A. \& Tulaczyk S. 2014. A decade of West Antarctic subglacial lake interactions from combined ICESat and CryoSat-2 altimetry. Geophysical Research Letters 41, 891-898, doi: 10.1002/2013gl058616.

Silva J.S.D., Calmant S., Seyler F., Filho O.C.R., Cochonneau G. \& Mansur W.J. 2010. Water levels in the Amazon Basin derived from the ERS 2 and ENVISAT radar altimetry missions. Remote Sensing of Environment 114, 2160-2181, doi: 10.1016/j.rse.2010.04.020.

Smith B.E., Fricker H.A., Joughin I.R. \& Tulaczyk S. 2009. An inventory of active subglacial lakes in Antarctica detected by ICESat (2003-2008). Journal of Glaciology 55, 573-595, doi: 10.3189/002214309789470879.

Tulaczyk S., Kamb B. \& Engelhardt H.F. 2010. Estimates of effective stress beneath a modern West Antarctic ice stream from till preconsolidation and void ratio. Boreas 30 , 101-114, doi: 10.1111/j.1502-3885.2001.tb01216.x.

Wang F., Bamber J.L. \& Cheng X. 2015. Accuracy and performance of CryoSat-2 SARIn mode data over Antarctica. IEEE Geoscience and Remote Sensing Letters 12, 1516-1520, doi: 10.1109/LGRS.2015.2411434.

Willis I.C., Pope E.L., Gwendolyn J.-M., Arnold N.S. \& Long S. 2016. Drainage networks, lakes and water fluxes beneath the Antarctic Ice Sheet. Annals of Glaciology 57, 96-108, doi: 10.1017/aog.2016.15.

Willis M.J., Herried B.G., Bevis M.G. \& Bell R.E. 2015. Recharge of a subglacial lake by surface meltwater in northeast Greenland. Nature 518, 223-227, doi: 10.1038/ nature 14116.

Wright A. \& Siegert M. 2012. A fourth inventory of Antarctic subglacial lakes. Antarctic Science 24, 659-664, doi: 10.1017/ S095410201200048X.

Wright A.P., Siegert M.J., Brocq A.M.L. \& Gore D.B. 2008. High sensitivity of subglacial hydrological pathways in Antarctica to small ice-sheet changes. Geophysical Research Letters 35, 179-190, doi: 10.1029/2008gl034937

Zwally H.J., Li J., Robbins J.W., Saba J.L., Yi D. \& Brenner A.C. 2015. Mass gains of the Antarctic Ice Sheet exceed losses. Journal of Glaciology 61, 1019-103, doi: 10.3189/ 2015JoG15J071.

Zwally H.J., Schutz B., Abdalati W., Abshire J., Bentley C., Brenner A., Bufton J., Dezio J., Hancock D. \& Harding D. 2002. ICESat's laser measurements of polar ice, atmosphere, ocean, and land. Journal of Geodynamics 34, 405-445, doi: 10.1016/S0264-3707(02)00042-X. 